\title{
Rhinos Come to Swaziland
}

THE FPS has presented to the Mlilwane Game Sanctuary, in 1 Swaziland, two square-lipped (white) rhinos brought from the Umfolozi National Park in Natal. Mlilwane is the only reserve, and these are the only white rhinos, in Swaziland. The reserve is the enterprising private venture of $\mathrm{Mr}$. Terence Reilly, who is trying to develop it, with government blessing, into a microcosm of Swaziland's former wildlife. The Umfolozi Park has a surplus of square-lipped rhinos, thanks to careful conservation measures in recent years under Colonel J. Vincent and his able staff. The two rhinos were collected on February 9th in two 6-ton lorries, one loaned for the occasion and driven by Mr. Nigel Maughn-Brown. The fuel for the lorries was given by the Shell Co. of South Africa. The rhinos travelled well, said Mr. Reilly, and were settling down satisfactorily in a cabled 2-acre paddock in which they were being acclimatised.

Mlilwane is open to visitors and Mr. Reilly has built a rest camp to accommodate sixteen people. The species he has collected include kudu, zebra, waterbuck, blesbok, impala, oribi, serval, and genet. He is now anxious to expand the reserve and, if he can raise the necessary money, buy 350 acres of virginal land on the western boundary. This would extend the reserve up to the mountain on that side and ensure that no farming operations were started on the edge of the sanctuary.

\section{THE FIRST RHINO CALVES BORN IN THE KRUGER}

THE Kruger National Park has been taking square-lipped rhinos from 1 the Umfolozi Park for the past three years. Mr. C. J. Venter, the assistant liaison officer of the National Parks Board, reports that eighty-six rhinos have now been transferred, most of them between November, 1963, and October, 1964. In November, 1964, came the exciting discovery of the birth of a calf, which was seen by four rangers-the first calf to be born in the park-and since then two more have been seen. The square-lipped rhino had become extinct before the park was declared, and for thirty-five years the authorities have been trying to get animals to build up a population. Two things made this possible in 1961: the Umfolozi surplus and the great improvement in immobilising techniques and drugs, largely the work of Dr. A. M. Harthoorn of the University College of East Africa in Nairobi. The first animals offered by the Natal Parks Board were taken in 1961. The cost of transport was borne by Messrs. Total Oil Products.

Later the procedure was greatly simplified : once a week a ranger and a mechanic from the Kruger National Park drove a large truck and trailer with two empty crates to the Umfolozi Park. Next morning a game ranger there hunted down and immobilised two rhino which were crated immediately; by nightfall they were on their way to the Kruger.

The birth of the calf is most encouraging, and another incident that the authorities regard as showing that the rhinos have settled down was when a bull rhino charged a pride of lions and sent one male lion clean through the strong boundary fence. 


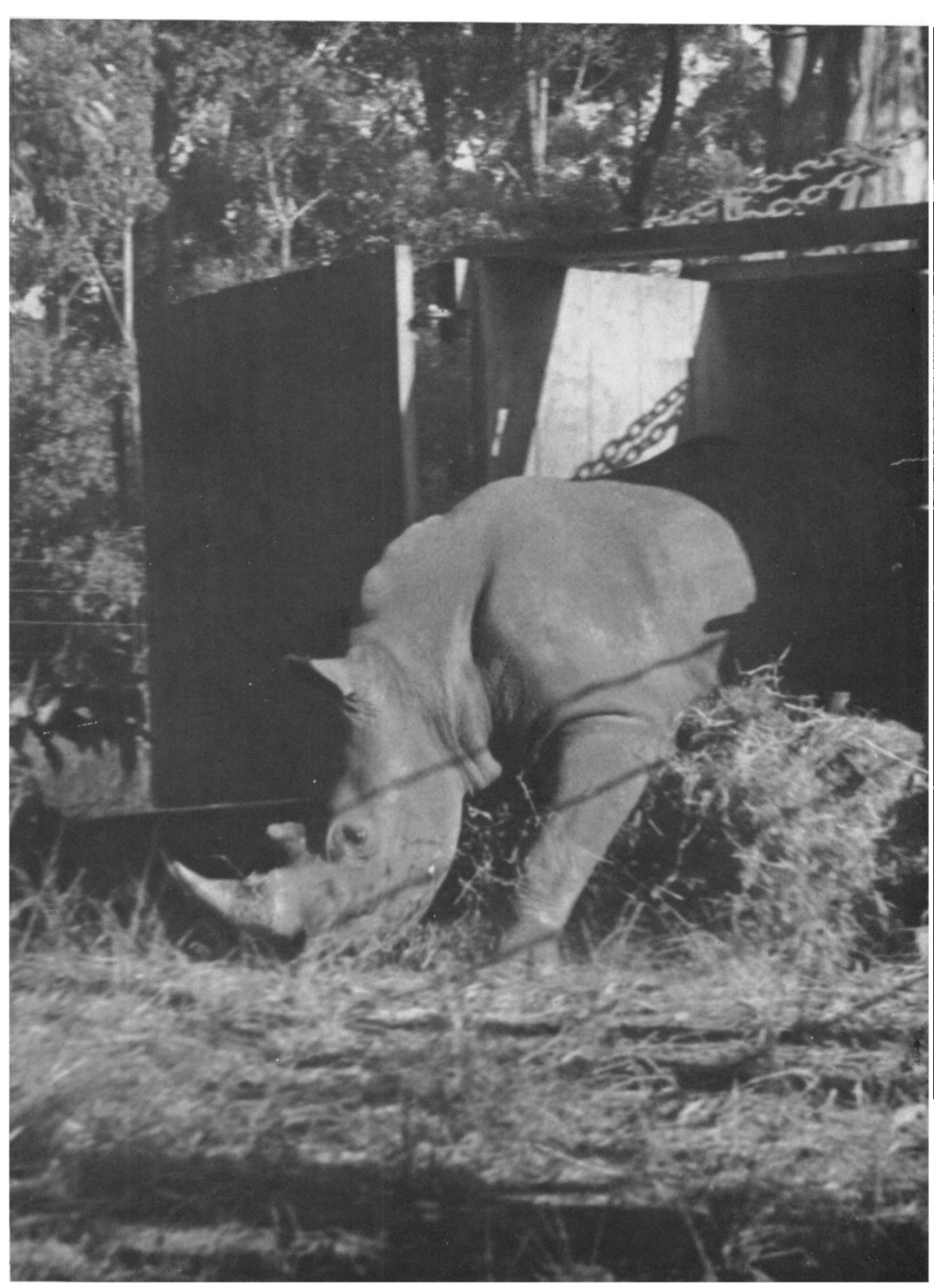

H. D. Kirk

THE RHINOS ARRIVE IN SWAZILAND

Plate 8: The first square-lipped rhino to be released at Mlilwane emerges from

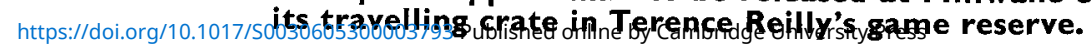




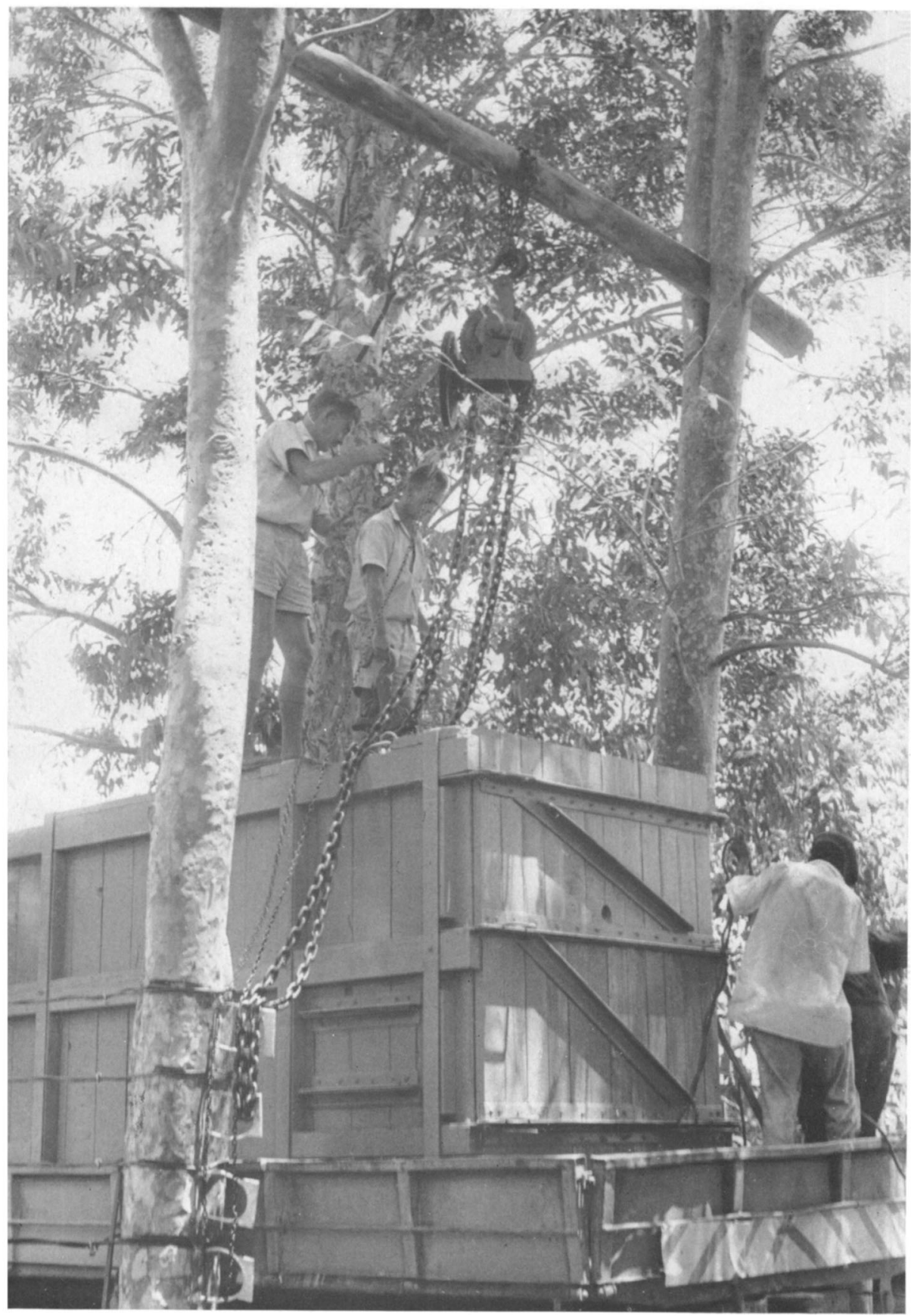

H. D. Kirk

\section{WHAT IT TAKES TO MOVE A RHINO}

Plate 9: Terence Reilly helps to get one of the rhino crates off the truck on arrival at Mlilwane. 


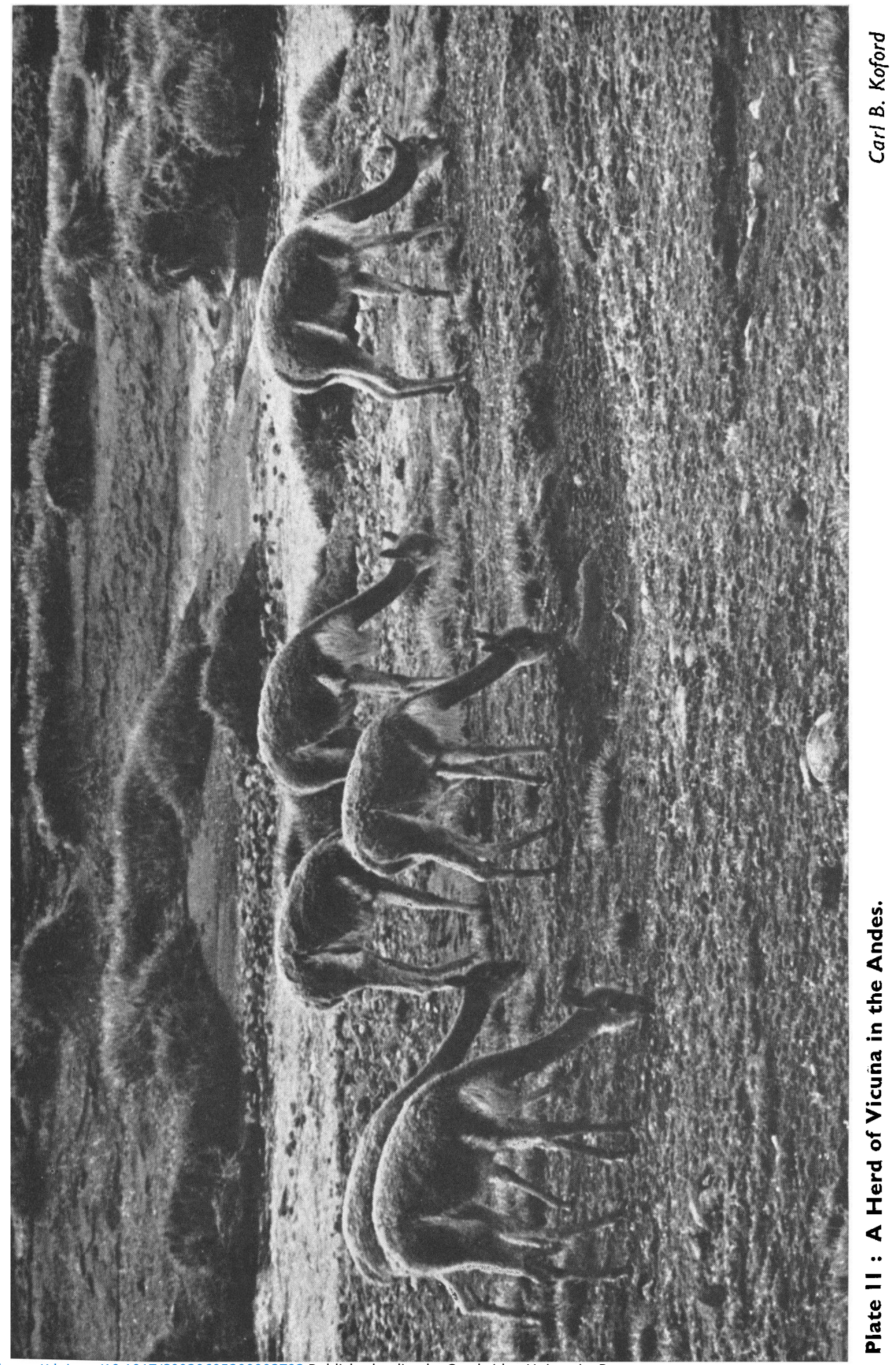


(continued from $p .31$.)

species. Most of the whales killed are "cachalotes" or sperm whales, which come into the warm waters near Paita, a port in northern Peru, to feed on the octopus. According to the government report more than 2,000 whales are killed annually off the coast and, since Peru insists on a territorial sea or closed area of 200 miles, no other nation can send its whaling ships along the coast where most of the whales congregate. So close in are they that no factory ships are needed; the Peruvian killer boats simply dart out from the Paita and the two other ports, kill their 30-ton quarry, and tow it back to port where the carcass is cut up. The females and young are easily recognised as they are much smaller than the blue whales. Supposedly protected, they are in fact often killed.

The vicuña is in very bad shape. Despite strict laws against killing them and selling the skins, the Indians of the high Cordillera, tempted by prices as astronomic as $\$ 100$ for a single pelt, continue to poach these little animals. There is no estimate of the numbers of wild vicunas remaining but the prices paid for their fur indicate that they are now extremely hard to find. Few of the vicuña skins are sold in Peru on account of the stiff fines, but there are no laws against selling them in Bolivia, and a regular traffic goes on there. Efforts to persuade the Bolivian Government to do something about this have so far come to nothing. The position may well be that no government can today enforce game laws among the hungry Indians of the high Andes.

Another resident of the high Cordillera is the chinchilla, a squirrel-like little animal with a coat that enraptures some women and may well bring about its extinction. A wild chinchilla wrap in New York, if available at all, may sell for $\$ 50,000$. Except in captivity the Peruvian chinchilla, known as the royal chinchilla, may now be extinct. Again, price tells the sad tale. In 1900 the skins were $\$ 6$ a dozen and by 1930 had risen to $\$ 200$ each. Since then the rewards have been so high that the Indians hunt them with dogs and weasels, and only in the virtually inaccessible peaks may they still survive. There are three races : the Peruvian, which commands the highest price; the Bolivian, which comes cheaper, and the Chilean, which is the least expensive. Chinchillas take 111 days to whelp and have only three litters a year. The Incas appreciated the silver and black coats of these little mountain animals and gave them protection. It seems an ironic commentary that wildlife flourished under the protection of absolute rulers while it faces extinction under the "enlightened" republics. The mountain areas still hold remnants of the vicuña herds, perhaps a few chinchilla, and some spectacled bears and small mountain deer known as the guemal. I urged the President to declare a park for vicuña in the Andes and have reason to believe that his government is seriously considering such a wise move.

Some species of wildlife, however, get full protection in Peru. These are the cormorants, pelicans and boobies which produce guano, the vital fertiliser which nourishes Peru's crops. But twenty years ago an enterprising fisherman discovered that he could make more money catching the anchovies, on which these birds depend for food, and selling them as fish meal, than he could by netting the larger fish. As a result the guano yield 
has been reduced by 50 per cent in the past decade. From a total catch of only about 200 tons in 1944, the industry now exports $1 \frac{1}{4}$ million metric tons of fish meal a year with a value of more than $\$ 120$ million. This of course means that there are fewer fish for the guano birds, and consequently less fertiliser for Peru's agriculture. Since 1956, when 330,000 tons were gathered from Peru's 48 guano-producing islands and 16 promontories, the total has dropped to 150,900 tons, indicating a net decline of more than 50 per cent in the number of guano birds. Not only do the birds die of starvation because there are fewer anchovies to feed on, but many become entangled in the fishermen's nets and drown.

Peru has only two parks. Cutervo of 6,250 acres, and Cueva, a tiny sanctuary of 78 acres. Neither park is patrolled but the rare birds of Cueva are looked after by the staff of the agricultural station there. The guacharo Steatornis caripensis, a very rare bird, still survives in this little park. In sharp contrast to these two modest wildlife reserves, Peru has proclaimed more than $12 \frac{1}{2}$ million acres of forest reserves, of which there are now sixteen, almost all in the jungle country of the Selva, and none on the forested Eastern slopes of the Andes where some of the country's rarest animals and plants are now under increasing pressure from man. Dr. Paul C. Hutchinson, a botanist from the University of California and director of that University's present expedition to the Andes, told me that the vicious cycle of roads, people, goats and erosion are having a tragic effect on these high forests. When he made an expedition there in 1957 he discovered a new species of cactus. Recently he returned to the area and found that the cactus had been entirely wiped out by goats.

The future of conservation in Peru, in fact, rests entirely on enforcement. Unless a force of trained and dedicated wardens can be developed, the mere proclaiming of land is useless. The Cutervo National Park was founded in 1961 , but it exists only on paper.

\section{CHILE}

Chile has more game reserves on the books than any country in South America, but the nineteen parks and twenty-six forest reserves have little significance, for in most of them people are living, and people always mean poaching and fires. The President of Chile, in fact, is authorised by law to settle families on 80 per cent of the arable land of the national parks. As a result Chile's wildlife is declining. The little indigenous Chilean deer is scarce; the Chilean condor is shot and becoming rare. The puma is under heavy pressure from hunters; at one hacienda in the south forty were killed in a single month. The rare James flamingo, however, which exists in limited numbers on the borders of Bolivia and Chile, seems to be in pretty good shape. A belated effort is being made to tighten enforcement. The fine for hunting or fishing without a licence is now 100 escudos, about $\$ 25$ as against the former nominal penalty of $\$ 2$. The licences themselves cost about $\$ 1.50$ each, but the revenues from this source and from fines do not go to the Fish and Game Department; they are merely added to other national income.

The Foreign Minister, Sr. Julio Philippi, is a keen conservationist and before I left he agreed to consider the formation of a game reserve on one 
of the islands in the Magellan Straits where people could be excluded and adequate protection afforded by the Chilean navy and air force.

\section{ARGENTINA}

The second largest country in South America, Argentina extends 2,150 miles from the sub-tropics on the Brazilian border to the icy wastes of Tierra del Fuego, and includes the habitats of some diverse animals and birds. It has the largest system of national parks in South America and has every right to be proud of them. However, $4 \frac{1}{2}$ million acres of reserve are policed by only 50 wardens and the entire budget for their maintenance is only $\$ 100,000$ annually. Furthermore a vocal group in the national legislature is seeking to remove the parks from federal control and place them under the provincial authorities, where they would immediately become the pawns of local politics. This threat has been staved off so far but it is far from removed.

Largest and most spectacular of the parks is the Nahuel Huapi National Park in the Andes on the Chilean border. In the park's nearly two million acres are found two rare Andean deer, the huemal and the pudu, as well as the guanaco and vicuña. There may also be a few chinchilla. Up on the Brazilian border is the Iguazu National Park, in whose 137,000 acres of forests are found jaguar, ocelot, tapir and capybara. At the other extreme of the country is the Tierra del Fuego National Park of 162,000 acres where there are some wild guanacos and numerous birds. Dr. Enrique Saporit, director of the zoo in Buenos Aires, told me that guanacos, while nominally protected, are shot all year round. The nutria and the Patagonian hare, a strange creature with short ears and the hind quarters of a little deer, are also being shot out. The cervo de la pantano, a small splay-footed deer found in the swamps of the La Platte estuary, is now so hard to find that the zoo has none although the habitat is only a few miles away. Dr. William Partridge told me that both species of rhea are getting scarce, and that the smaller one, Darwin's rhea, is now extinct in many districts of Patagonia. Rheas are killed for their feathers which are made into dusters to clean cars.

Since most of the land of Argentina is privately owned and such game laws as there are stop at the gates of the estancias, the choice of conserving or destroying wildlife is largely a private matter. A hunting licence costs less than a dollar and most people don't bother to get it.

\section{URUGUAY}

Uruguay's park system is complicated by too many cooks. The Ministry of Defence runs Santa Teresa, the only area large enough to be called a national park, while the Ministry of Public Works has jurisdiction over five little reserves. But the Ministry of Agriculture, which is responsible for all the nation's wildlife, has no parks at all. The fur seals and sea lions are protected and killed for their pelts. There are roughly 80,000 fur seals and 30,000 sea lions and approximately 28 per cent of the total are killed yearly for their hides. Otherwise little effort is made to preserve Uruguay's small population of animals; except for the small indigenous deer, a few capybaras and a plethora of nutrias (coypu), there is none. The puma, the fox (warrah), the swamp deer (tatu) and the 
anteater (coendu) have ceased to exist there. Birds are in better supply, but most of these are not indigenous to Uruguay. The only endangered species, according to the museum ornithologists, are the perdiz-grande, (big partridge), a species of tinamou; and the cisne cuello negro, the black-headed swan. Both species are nominally protected under the existing laws but both are also shot by almost everyone whenever possible. Virtually all the land in Uruguay is privately owned, and, since the tiny staff of wardens have no authority to enter, what is or is not shot is entirely a matter of the conscience, or knowledge, of the estancia owner.

I tried to persuade President Luis Giannattasio and his Minister of Agriculture, Wilson Aldunate, that Agriculture should also run the Santa Teresa Park, and that Kaguna Negra, a 50-square-mile lake which adjoins Santa Teresa, be added to it so that the waterfowl would also enjoy some protection. I believe both my suggestions will be carried out.

Why most Uruguayans (and for that matter most Latin Americans) shoot everything which moves makes an interesting sociological study. About half the nation is of Spanish descent and half of Italian. Both races come from ancient lands where the fauna, except on the private estates of the nobility, has long ago been exterminated and perhaps because of this they equate democracy with the right to kill at will. In Mexico many years ago, I asked a man why he had killed a hawk-in this case a perfectly innocent hawk which fed largely on mice-and he replied, "because it was flying away."

\section{THE FALKLAND ISLANDS}

Conservation is doing all right in this remote British colony. Seventeen of the 202 islands which make the 4,618 square mile area of the archipelago will become sanctuaries if a bill about to go before the Legislative Council becomes law and there is no reason to believe that it will not. At the same time a six-month close season for game birds will be considered. The Falklands have an important population of penguins, and other birds of the seas as well as some land birds. Sixty species of birds breed there of which sixteen are endemics. Three birds should have special protection : the Johnny Rook or caracara, a small hawk; the king penguin, which is just starting to return to the islands, and whose breeding place is kept a secret, and the macaroni penguin which is also a rare visitor to the islands.

Mammals consist of sea lions, sea elephants and a few fur seals, and very little data is available on them. The last census of sea lions was made by Hamilton in 1934, and since then the numbers of pups born on the islands are said to have decreased drastically. The last elephant seal count was made in 1953 by Laws, who estimated that not more than 1,000 pups were born each year. The fur seal position is even more obscure and some of the data, such as the report of seals on Beachene Island in 1962 by H.M.S. Protector, is incorrect. An up-to-date survey is badly needed.

The story of the Falklands' only large land mammal is a sad one. The Falkland fox, sometimes wrongly called a wolf, joined the dodo when the last one was shot at Shallow Bay, West Falkland, in 1876. There was no reason for this, for a gentler member of the canine tribe it would be hard to find. Darwin reported that gauchos would hold out a piece of meat and 
knife the trusting foxes while they nibbled the offering. In 1839 the New York fur trader, John Jacob Astor, sent a vessel to the islands to buy up all the skins she could hold, and thousands of foxes were slaughtered. The only skins now preserved are four which Captain FitzRoy of the Beagle gave to the British Museum ; from them we know that the Falkland fox stood about fifteen inches and had a soft thick coat of rich brown fur with a white belly and white lower jaw. The Falkland fox kept down the upland goose, a voracious grass eater which competes with the sheep for the pasturage, so that when it became extinct foxes were imported from the Argentine. These soon became so prolific that they attacked the lambs and had to be shot. They are now only found on Weddell and Beaver Islands. Hares were introduced on the East Falklands and rabbits on the West. During the war when a battalion of the West Yorks was stationed on the islands, the officers imported some beagles and there are said to be a few mongrels in Port Stanley which still show traces of this sporting infusion.

\section{THE FUTURE}

The future of conservation in South America depends primarily on education. The average male likes to shoot, and lets go at virtually everything which moves and can't shoot back. Such game laws as exist have virtually no significance because they are seldom, if ever, enforced. In most countries I visited, enforcement is a minor function of the police who regard it either as an unwelcome addition to their duties or as a means of supplying their larders. The net of it is that neither the public nor the minions of the law really know what the game laws are; and since the fines for breaking them are less than nominal, a tacit agreement to ignore them exists. A broad programme of education, aimed at teaching the young the importance to themselves of their wildlife heritage, might conceivably have some ultimate results. I urged the adoption of this basic phase of conservation with presidents, ministers and directors of the various national wildlife services. A few tentative efforts have been made along this line. A booklet explaining and illustrating the fauna of Peru has been distributed in the schools, and the Minister of Education in the Argentine told me steps are being taken to include a course on conservation in the teachers' college. But a great deal more could be done at a relatively small cost.

\section{The Vicuña}

SINCE Ambassador Crowe's visit to South America, further efforts have Sbeen made in Argentina, Peru, and Bolivia to protect the vicuña, and especially to stop the smuggling from Peru into Bolivia. According to The Times correspondent in Lima, the total vicuña population is estimated at about 400,000 , of which 240,000 live in the Peruvian Andes. But Bolivia sells about 5 tons of vicuña wool a year to the US (some is also coming to Britain), and because of the near impossibility of shearing these timid animals without killing them this represents the death of between 20,000 and 40,000 vicuñas a year. Extinction is not far away at this rate. One Peruvian farmer has built up a domesticated herd of about 500 vicunas, but owing to the small wool yield it is far from economic, and domestication is likely to remain so unless it proves possible to breed a strain of better wool-bearers, as has been done with sheep. 